\title{
Public Service Motivation: The Teaching Performance of Biology Teachers
}

\author{
Suhirman and Yusuf \\ Universitas Islam Negeri Mataram, West Nusa Tenggara, Indonesia
}

Corresponding author: suhirmanmawal@gmail.com

\begin{abstract}
The public service motivation plays a central role in improving to teaching performance of biology teachers. The objective was to explore the impact of Public Service Motivation (PSM) on the Teaching Performance (TP) of biology teachers at Madrasah Aliyah in Central Lombok Regency. The formulation of the problem is whether there is an effect of PSM on the teaching performance of biology teachers in Madrasah Aliyah. The research method employed was a quantitative approach. Statistical calculations showed that the correlation value (r) between the PSM and TP variables was 0.278 . This correlation value was positive. The output also revealed that Sig. (2-tailed) Of 0.124 , was the probability value that would compare with alpha (significance level). In this study, researchers set $\alpha=5 \%$ or 0.05 . Thus, because of Sig. (2-tailed) 0.124 was more significant than 0.05 , H0 was accepted, meaning that the correlation between the PSM and TP variables occurred insignificantly. From the result, it can conclude that PSM has a positive association with the TP of biology teachers at Madrasah Aliyah in Central Lombok Regency by 0.278, but the correlation is not significant.
\end{abstract}

Keywords: Biology Teachers; Public Service Motivation; Teaching Performance.

\section{Introduction}

The teaching performance of biology teachers is confronted with highly complex and challenging tasks (Broekema et al., 2019). However, the supposed relationship between PSM and performance itself has received little attention in research to date (Leisink and Steijn, 2009). Prior research has documented the pernicious effects of professional education on prosocial and public service motivations (Ponomariov and Mccabe, 2017). PSM research initially neglected the effect of context on motivation (Andrews, 2015). In the past three decades, increasing the teaching performance of biology teachers has been implemented as public service motivation throughout the area West Nusa Tenggara including the Central Lombok Regency, West Lombok Regency, and East Lombok Regency. However, the teaching performance of biology teachers in providing public services at an Islamic high school level is still considered low.

The emergence of PSM is mainly intended to reform management in the education sector. Open benefits in the domain of instruction have been continuous as a component of "less beneficial" and "wasteful" associations. The negative image attributed to the educational institution cannot be isolated from the performance of an organization that has not yet satisfied its stakeholders. Many research indications that find positive associations between PSM and TP. PSM can be an important element in explaining high performance (Loon et al., 2018). Most of the research on the relationship between PSM 
and performance use subjective performance data and focus on output rather than the outcome (Andersen et al., 2014).

A competent educational institution has a high motivation to improve its management quality, which covers PSM, mission motivation, and task motivation. There are motivational differences among the teachers who teach in the education sector. This belief confirms that there should be variation in the efforts to increase working motivation among the teachers in improving the quality of educational institutions and services provided to students (Andersen et al., 2014). Motivation is an important determining factor of the individual aware and responsible option for a specific career. Concerning student's opportunity for becoming teachers, the reasons may be different: the availability and stability of employment, working hours, perception of personal skills, challenges, and satisfaction that it brings the practice of the profession, and the social importance of occupation (Albulescu and Albulescu, 2015). Motivation is the trigger for the initiation of activity as well as for the persistence in completing or abandoning a particular task. For that reason, we can safely infer that motivation is one of the critical factors with a significant impact on performance (Albulescu and Albulescu, 2015). Motivation is an effective factor that makes human organisms behave, determine the decisiveness and energy of that behavior, and keep the routines going by directing them. For example, motivation towards science lessons, motivation to technology lesson, because educationalists, who study the causes of failure in the classes, are curious about the effect of the motivation about success (Ekici, 2010).

PSM is an individual's orientation to delivering service to people to do good for others and society (Ugaddan \& Park, 2015). PSM has a direct effect on performance, job satisfaction, organizational commitment (Palma, 2016). PSM can play a key role in governing behavior (Cheng, 2015). Perry developed the public service motivation scale measuring attitudes along four dimensions (subscales): attraction to public policymaking, commitment to the public interest/civic duty, compassion, and selfsacrifice (Johnson, 2010). To upgrade the showing execution in the instruction unit, the teachers' performance should be improved (Meng \& Wu, 2017).

PSM is a unique part of the motivation. It can be defined as the one consisting of belief, value, and attitude which go beyond personal and organizational interests, and it encourages an employee to do goods to others and contribute to the welfare of the organization and society (Seider et al., 2011). It means that a positive public service motivation will certainly produce competent and dedicated employees for their duties and obligations, and they can improve their working performance. Theoretically, PSM is defined as an individual's tendency to respond to unique basic motives in public institutions and organizations. This theory is based on the opinion that there are people who are interested and motivated to work in the public sector. The higher the PSM an individual has, the more likely it is to work in the public sector (Seider et al., 2011).

Developments in biology have particularly emphasized the significance of biology and who know the nature of science biology can analyze the problems they encounter 
(Ozcan et al., 2014). Biology is one of the courses that explain natural events (Gercek and Ozcan, 2015). Biology investigating interactions of living things with each other, and the environment is a branch of science (Çetin et al., 2014). As a discipline of science, biology includes many concepts that have complicated relationships with each other (Atav and Deniz, 2009). As biology includes complex links of unfamiliar and abstract concepts, it is quite challenging to learn and teach (Yapici and Hevedanli, 2012). Some of the goals of biology education include individuals' perceptions about the nature of science, scientific literacy, comprehension, and application of the scientific research process (Çobano et al., 2009).

Experienced teachers possess specialized knowledge, acquired during their teaching (Rozenszajn and Yarden, 2015). In biology teaching, the fact that educational situations and biology concepts are abstract and complex causes students to experience difficulty in understanding certain subjects and to learn them via memorization without understanding (Yapici and Hevedanli, 2012). The teaching of biology having a unique position because of its scientific and social (Yenice, 2009).

\section{Material and Method}

This research was quantitative and qualitative using observational design and a cross-sectional approach. In other words, this research employed a mixed method of quantitative and qualitative approaches. Data were collected through a structured questionnaire containing statements filled out by respondents using a Likert Scale and scores of the respondent's answers in each variable. The variables of PSM were measured with instruments adopted and modified from Kim et al. and adjusted to the need of the researchers. They consisted of attraction to public policymaking, commitment to the public interest and public value, compassion, and self-sacrifice. Meanwhile, the variables of teaching the performance of the teachers were measured with instruments adapted and modified from the Ministry of National Education using the indicators of teachers' performance assessment in planning, implementing, opening and closing, learning stimulus variations, questioning skills, and giving reinforcement.

The research was conducted on 32 samples of biology teachers at Madrasah Aliyah in Central Lombok Regency. Data on PSM was collected through a structured questionnaire containing statements filled out by respondents using a scale. The scores from the survey were analyzed using descriptive and inferential statistics.

\section{Results and Discussion}

\subsection{Results}

The research was conducted in 2018 by taking 32 samples of biology teachers at Madrasah Aliyah in Central Lombok Regency. Data on PSM was collected through a structured questionnaire containing statements filled out by respondents using a scale. 
Table 1. The results of an analysis of the correlation

\begin{tabular}{llcc}
\hline & PSM & TP \\
\hline PSM & Pearson Correlation & 1 & .278 \\
& Sig. (2-tailed) & & .124 \\
$\mathrm{~N}$ & 32 & 32 \\
$\mathrm{TP}$ & Pearson Correlation & .278 & 1 \\
& Sig. (2-tailed) & .124 & \\
& $\mathrm{~N}$ & 32 & 32 \\
\hline
\end{tabular}

Table 1 indicated that the correlation value ( $\mathrm{r}$ ) between the PSM and TP variables was 0.278 . It is is a positive correlation value. On the output, it was knowing that Sig. (2tailed) Were 0.124; the probability value that will compare with alpha (significance level). In this study, the researchers set $\alpha=5 \%$ or 0.05 . Thus, since Sig. (2-tailed) 0.124 was greater than 0.05 , H0 was accepted according to the rule.

\subsection{Discussion}

PSM of biology teachers at Madrasah Aliyah could be classified into a high category. This is implied that the biology teachers at Madrasah Aliyah in Central Lombok Regence had a strong desire to perform their professional duties as teachers. The strength of this motivation was based on knowledge and awareness of the religion. PSM can play a key role in governing behavior, and public service-motivated employees in public organizations are expected to work better and harder and obtain better results (Cheng, 2015). That PSM are complementary theoretical approaches and can provide clearer guidance to practitioners and widen the understanding of motivation in public services (Andrews, 2015).

The teachers' performance at Madrasah Aliyah in Central Lombok Regency can be classified into the moderate category. This category means above low and below high category. It further implied that the teachers of biology subject at Madrasah Aliyah in Central Lombok Regency performed their professional duties well. The duties involved instructional planning skills, designing instructional activities, evaluating learning outcomes, asking skills, reinforcing skills, creating variation skills, explaining skills, opening and closing lessons, classroom management skills, individual teaching skills, educational aspects, professionalism development, and tools for the instructional process. Based on the value of deviation standard (13.86), it was known that the value is minimal, and it indicates that the teachers' performance values did not differ a lot from the average value. Hence, the performance of biology teachers at Madrasah Aliyah in Central Lombok Regency is equal in the medium category. Distribution of the respondents' responses in percentage based on the choices on performance questionnaire $(\mathrm{SL}=$ always $(19,17 \%), \mathrm{SR}=$ frequently $(31,93 \%), \mathrm{KD}=$ sometimes $(25,68), \mathrm{JR}=$ rarely $(10,73), \mathrm{TP}=$ never. 
The data in table 1 shows that the respondents' propensity for always stating (SR) and often (KD) is very high. The smallest percentage is the choice for rarely (JR). This KD underlines that the performance of biology teachers at Madrasah Aliyah in Central Lombok Regency was on the average category. Our findings also suggest that it can be essential to study the role of publicness as referring to institutional characteristics that create or limit opportunities to contribute to society through the job in determining the relationship between PSM and performance (Loon et al., 2018).

In addition to the total performance above, this study also presented the performance of every aspect, becoming the dimension of the teachers' performance in carrying out their professional duties. The result of the analysis revealed that all of the dimensions are of medium category in general. However, there were two dimensions of the teachers' performance, which obtained lower results, namely professionalism development and tools for instructional process aspects. Comparison of the dimensions of performance scores of biology teachers at Madrasah Aliyah in Central Lombok Regency: instructional planning skills $(4,1)$; designing instructional activities $(3,0)$; evaluating learning outcomes $(3,2)$; asking skills $(3,9)$; reinforcing skills $(3,9)$; creating variation skills 3,4$)$; explaining skills $(4,0)$; opening and closing lessons $(3,1)$; classroom management skills $(3,8)$; individual teaching skills $(3,3)$; educational aspects $(3,3)$; professionalism development 91,7); tools for instructional process $(2,1)$. Having indepth pedagogical knowledge is one way to improve teacher teaching practices (Großschedl et al., 2014). PSM can play a key role in governing behavior, and public service-motivated employees in public organizations are expected to work better and harder and obtain better results (Cheng, 2015). The quality of administrative leadership is positively and significantly related to PSM (Ugaddan \& Park, 2015).

Based on the results, it can conclude that PSM is positively correlated with the performance of biology teachers (0.278) at Madrasah Aliyah in Central Lombok Regency, but the correlation is not significant. Due to the concept's emphasis on public values, PSM research initially neglected the effect of context on motivation (Andrews, 2015). the research suggests a no effect or weakly positive effect driven by marginally increased levels of commitment to the public interest (PSM subscale) (Ponomariov and Mccabe, 2017). Prosocial motivation is positively related to employee proactivity (Patil and Lebel, 2019). PSM is associated with higher performance, and this result is stronger, the longer the students have been taught by a high-PSM teacher (Andersen et al., 2014). PSM would enable contributed to the growth in teacher performance (Leisink and Steijn, 2009). PSM is an individual's orientation to delivering service to people to do good for others and society (Liu et al., 2014).

\section{Conclusion}

This study suggests that the correlation between public service motivation and teaching performance was not significant. However, this finding implies public service 
motivation and teaching performance aimed at improving teaching effectiveness in public high schools.

\section{References}

Albulescu, M., \& Albulescu, I. (2015). Motivational benchmarks for teaching career choice. Procedia-Social and Behavioral Sciences, 209 (July), 9-16. https://doi.org/10.1016/j.sbspro.2015.11.219

Andersen, L. B., Heinesen, A., \& Holmpedersen, L. (2014). How Does Public Service Motivation Among Teachers Affect Student Performance in Schools? Journal of Public Administration Research and Theory, 24, 651-671. https://doi.org/10.1093/jopart/mut082

Andrews, C. (2015). Integrating public service motivation and self-determination theory. International Journal of Public Sector Management, 29(3), 238-254. https://doi.org/10.1108/IJPSM-10-2015-0176

Atav, E., \& Deniz, B. (2009). Perception of pre-service teachers about their competence in biology applications. Procedia - Social and Behavioral Sciences, 1(1), 1278-1284. https://doi.org/10.1016/j.sbspro.2009.01.227

Broekema, W., Porth, J., Steen, T., \& Torenvlied, R. (2019). Public leaders' organizational learning orientations in the wake of a crisis and the role of public service motivation. Safety Science, 113(November 2018), 200-209. https://doi.org/10.1016/j.ssci.2018.11.002

Çetin, G., Kübra, G., \& Algan, N. (2014). Prospective biology teachers' views about Turkish videos related to parts and usage of microscope. Procedia - Social and Behavioral Sciences, 116, 2784-2789. https://doi.org/10.1016/j.sbspro.2014.01.656

Cheng, K. (2015). Public service motivation and job performance in public utilities An investigation in a Taiwan sample. International Journal of Public Sector Management, 28(4/5), 352-370. https://doi.org/10.1108/IJPSM-08-2015-0152

Çobano, E. O., Sahin, B., \& Karakaya, Ç. (2009). Examination of the biology textbook for 10 the grades in high school education and the ideas of the pre-service teachers. Procedia - Social and Behavioral Sciences, 1, 2504-2512. https://doi.org/10.1016/j.sbspro.2009.01.442

Ekici, G. (2010). Factors affecting biology lesseon motivation of high school students. Procedia Social and Behavioral Sciences, 2(2), 2137-2142. https://doi.org/10.1016/j.sbspro.2010.03.295

Gercek, C., \& Ozcan, O. (2015). Views of biology teacher candidates about context based approach. Procedia - Social and Behavioral Sciences, 197(February), 810-814. https://doi.org/10.1016/j.sbspro.2015.07.190 
Großschedl, J., Konnemann, C., \& Basel, N. (2014). Pre-service biology teachers' acceptance of evolutionary theory and their preference for its teaching. Evolution: Education and Outreach, 7(18), 1-17. https://doi.org/10.1186/s12052-014-0018-z

Johnson, B. J. (2010). City planners and public service motivation. Planning Practice \& Research, 25(5), 563-586. https://doi.org/10.1080/02697459.2010.522854

Leisink, P., \& Steijn, B. (2009). Public service motivation and job performance of public sector employees in the Netherlands. International Review of Administrative Sciences, 75(1), 35-52. https://doi.org/10.1177/0020852308099505

Liu, B., Zhang, X., \& Lv, X. (2014). Compassion as the affective dimension of public service motivation in a Chinese context. Social Behavior and Personality, 42(2), 245-252.

Loon, N. Van, Kjeldsen, A. M., Andersen, L. B., Vandenabeele, W., \& Leisink, P. (2018). Only When the Societal Impact Potential Is High ? A Panel Study of the Relationship Between Public Service Motivation and Perceived Performance. Review of Public Personnel Administration, 38(2), 139-166. https://doi.org/10.1177/0734371X16639111

Meng, F., \& Wu, J. (2017). Policy expectation moderates the relationship between merit pay policy effectiveness and public service motivation. Social Behavior and Personality, 45(November 2013), 1305-1318.

Ozcan, T., Ozgur, S., Kat, A., \& Elgun, S. (2014). Identifying and comparing the degree of difficulties biology subjects by adjusting it is reasons in elementary and secondary education. Procedia - Social and Behavioral Sciences, 116(266), 113-122. https://doi.org/10.1016/j.sbspro.2014.01.177

Palma, R. (2016). Public service motivation and employee outcomes in the Italian public sector : testing the mediating effect of person-organization FIT. Journal of Applied Quantitative Methods, 11(2), 1-17.

Patil, S. V, \& Lebel, R. D. (2019). "I want to serve, but the public does not understand :" Prosocial motivation, image discrepancies, and proactivity in public safety. Organizational Behavior and Human Decision Processes, 154(July), 34-48. https://doi.org/10.1016/j.obhdp.2019.07.002

Ponomariov, B., \& Mccabe, B. (2017). Professionalism vs. Public Service Motivation: Can Public Administration Education Alleviate the Tension? Administrative Theory \& Praxis, 39, 80-99. https://doi.org/10.1080/10841806.2017.1309802

Rozenszajn, R., \& Yarden, A. (2015). Studies in educational evaluation exposing biology teachers' tacit views about the knowledge that is required for teaching using the repertory grid technique. Studies in Educational Evaluation, 47, 19-27. https://doi.org/10.1016/j.stueduc.2015.06.001 
Seider, S. C., Rabinowicz, S. A., \& Gillmor, S. C. (2011). The Impact of philosophy and theology service-learning experiences upon the public service motivation of participating college students. The Journal of Higher Education, 82(5), 599-628.

Ugaddan, R. G., \& Park, S. M. (2015). Quality of leadership and public service motivation employee: a social exchange perspective on employee engagement. International Journal of Public Sector Management, 30(3), 270-285. https://doi.org/10.1108/IJPSM-08-2016-0133

Yapici, İ. Ü., \& Hevedanli, M. (2012). Pre-service biology teachers' attitudes towards ICT using In biology teaching. Procedia - Social and Behavioral Sciences, 64, 633-638. https://doi.org/10.1016/j.sbspro.2012.11.074

Yenice, N. (2009). Factors that affect teacher candidates' attitudes and successes towards biology. Procedia - Social and Behavioral Sciences, 1, 1372-1377. https://doi.org/10.1016/j.sbspro.2009.01.242 